\title{
Y and Z Generations at Workplaces
}

\author{
- Bencsik Andrea, Horváth-Csikós Gabriella, Jubász Tímea
}

\begin{abstract}
At present, more and more researches deals with the characteristic features of generation $\mathrm{Y}$ and generation Z. As it is about the present and future generations, corporate success and the competitive operation are determined by the behaviour of these generations in the long-run. Researches justifies that there are significant differences between the two generations despite the similarities. These differences appear rather emphasized in the corporate environment when several questions arise at workplaces in the process of cooperation - especially in the field of knowledge-sharing and knowledge transfer-regarding the characteristics of the two generations. Last year, the authors carried out a quantitative research by questionnaires in order to reveal what the managing of these two generations mean for the managers and also what difficulties occur when the two generations cooperate with each other and with elder generations as well. The main question of the research was how to approach the new generations from the view of HR?

Although the research cannot be considered representative (410 respondents participated in the survey), it can give a picture about the examined issues. The hypothesis phrased by the authors was justified according to which of the HR activities have to adapt to the requirements of the new generations upon their appearance.
\end{abstract}

Keywords: HR, intergeneration, knowledge-sharing $Y$ and $Z$ generation, behavior, work place JEL Classification: M10

\section{INTRODUCTION}

Human nature and the basic characteristics of our behavior are often in contrast with the organizational and corporate requirements for the sake of reaching and maintaining competitiveness. The same applies to the field of cooperation, and of knowledge-sharing as well. Corporate cooperation, teamwork and information flow between departments all depend on communication style, of which positive and/or negative impact - based on our way of thinking - can be best observed in the field of knowledge-transfer and knowledge-sharing. It is true for oral, written and electronic communication as well. The applied methods, corporate principles, regulations and tools influence the successful operation of the corporation through communication, but the consistency of the employees' age-tree influence the method of communication and knowledgetransfer. According to Davenport and Prusak (1998), knowledge-sharing -as a requirement- is unnatural, because people think that their individual knowledge is valuable and important. Piling knowledge and mistrust towards knowledge coming from others is natural. Although, providing knowledge-sharing - as managing condition - means pressure and opportunity at the same time for companies. Therefore it is important to encourage people to transfer their knowledge and to build trust. Several international researchers examine the connection between these two factors (Krishnan et al, 2013; Singh, 2014; Schaffer, 2015; Bencsik - Machova, 2015). With regard to this, the increase in the value of human resources, the utilization of results of mental activities 
in the corporate's activities and consequently, increasing the corporate's market competitiveness are a serious challenge for the management. Reaching the cooperation of different age-groups, managing conflicts originating from generational problems are aggravating factors in the challenge. These problems emerge more often in the field of knowledge-sharing. As a result of increasing the retirement age, it is often 3 or 4 generations who are forced to cooperate and to work together in the majority of companies. The difference between these age groups' way of thinking, attitude, behaviour and value system, their flexibility and their technical knowledge can easily become the source of several conflicts, and it is sometimes very difficult to manage these problems. Nowadays it is quite an up-to-date and unsolved issue how to manage requirements of the two youngest age-groups on behalf of serving the interest of knowledge-sharing by satisfying their requirements. There are corporate solutions, which are specifically forced by the youngest age-groups from the management (Singh, 2014). Such solutions are e.g.: opportunities of atypical employment, home-office or using technical devices where previously it was not typical; or ergonomics, as a workplace organizational solution has again come to the front, but there are other solutions in the front again, such as satellite workplace, hot desk, shared desk, open space, break out or mobile centre.

Beyond harmonizing the corporate processes with the operability of the knowledge-management systems, it assumes the presence of basics, which are manifested in culture, building trust, common thinking and the real cooperation. Based on the results of the research, it is obvious that the key-question behind the operability of knowledge-management is culture and it depends on the know-how of developing trust. In this case, the challenge for the management is easy to phrase.

As all the above mentioned is well-known, it is absolutely right to ask the question: if we know this all in theory, then why does not practice work? Why do managers have to cope with newer and newer unsolved situations (and sometimes the employees as well), and if they do not handle or simply ignore these situations, it is absolutely impossible to create the desired pre-conditions, which is the seal of the corporate's success, the operation of the knowledge-management system and knowledge-sharing. This is the development of the study-organization which is built on trust.

This paper aims to reveal the background and connections of those challenging problems which have to be handled essentially in order to step further. The mentioned managerial tasks created a new term in the professional literature and justified its implementation in corporate practice, which is called intergenerational management. This new managerial task means the recognitions and proper handling of problems originating from the cooperation of different generations; in our case, focusing on the role of knowledge-sharing. In order for the management to be able to take appropriate measures in the new situation, they have to be aware of the most important characteristic features which rank the workplace attitude of each generation. The authors give a brief review on them . 


\section{LITERATURE BACKGROUND}

It is difficult to terminate the groups of each generation precisely, but the time-lanes in the borders mean certain common territories. Therefore, the generations are not sharply divided, but their characteristic features are adequate for the whole age-group in general. Professional literature use different names for depicting the categories of the generations and their time-categorization is also sometimes differently defined. (Although it does not influence the basic characteristics). In the followings you can find the classification we used in our research. Characteristically, we can differentiate 6 generations which are shown in chronological order in Figure 1.

\begin{tabular}{|l|l|}
\hline \multirow{4}{*}{} & Veteran generation $(1925-1946)$ \\
\hline & Baby boom generation $(1946-1960)$ \\
\hline X generation $(1960-1980)$ \\
\hline & Y generation $(1980-1995)$ \\
\hline & Z generation $(1995-2010)$ \\
\hline & Alfa generation $(2010+)$ \\
\hline
\end{tabular}

Fig. 1 - Time-line of generations. Source: authors' construction (on the basis of Zemke et al., 2000);

A question should be put why it is necessary to deal with the topic. Why do we need to examine the behaviour of generations and their characteristics? Why do we need to think about an emphatic challenge, how these newer generations at workplaces of earlier generations can be fitted? The older generations have doubts about the younger ones every time and the often cited expression is 'these youngsters of today'. (It is not a positive opinion accent.) To tolerate the conventional differences among generations is insufficient nowadays. Why is this situation special? Why is it a hot issue? What does the term 'new generational employees' mean? What generational features cause bigger problems today in case of employing young graduates than earlier? All the questions cannot be answered in the framework of this article, but we present one portion of our research, which is mainly built on the behaviour of the generations. To answer these questions, firstly, the most important characteristics of generations have to be shown. Then the HR activities are presented briefly in order to show the readers the direction of the necessary changes.

\subsection{Characteristics of youngest generations}

Apart from detailed characterization of each generation, the paper rather focuses on the most important features of the target audience, the generation $\mathrm{Y}$ and generation $\mathrm{Z}$. Thus it prepares the readers' thoughts for evaluation of the questionnaire's research results.

Generation Y: Generation Y is also called millennium generation. (Schäffer, 2012) The ,Y‘ comes from the English word youth. They were the first wave of the digital generation born into the world of technology. They are highly qualified in digital knowledge; therefore it is easy for them to quickly acquire the use of new tools and devices in IT. They easily accept changes, they live for today, they do not like to plan for long periods; they rather want to enjoy themselves in their own world. Their circle of friends is virtual, they mainly nurse their relations on social sites, they eas- 
ily accept cultural differences and they really like living a quick life (Krishnan et al, 2012). Family is not everything for them, traditional values are fading. Majority of generation $\mathrm{Y}$ is already present at the labour market, they have university degrees and they work together with a lot of people from generation $\mathrm{X}$ and with fewer people from generation $\mathrm{Z}$. They possess unique ideas about their future positions at the workplaces. It is important for them to work where they want and to do what they really enjoy doing. If they feel that they are in captivity, they quickly step further. Generation Y is characterized by ,multitasking”, the multi-sided and shared attention (Schäffer, 2015). For them, the concept of success, career and money is of top priority, because they have learned that it is the only thing that can advance them in consumer society (Tari, 2010). Using modern technological devices, their communication mainly happens in the virtual space and their online presence is never-ending. They are motivated by pushing, advancing and reaching success, work is always highlighted for them and family remains in the background. The feeling of free-time and relaxation is inevitable for them, they have wide-spread and diverse desires; they usually make decisions or act accordingly to reach these goals. Money and success are basic motivational tools for them in their work, which come to the front opposite family values. From the view of success in the quality of life is important their work and it appears in their relaxation pointedly, as well. The desires, ambitions of newer generations are comprehensive, the young often grow out of their abilities and possibilities, therefore, their requirements culminate in varied forms. Their experience determine their decisions and actions (Bittner et al, 2013).

Generation Z: Generation Z has the features of „net generation”due to highly developed digital era, which they were born into. They were also characterized as „Facebook-generation”, „digital natives” or sometimes „iGeneration”. (Tari, 2011). The norms of generation Z are different from the norms of the previous generation. Words, slangs and expressions used by generation $\mathrm{Z}$ are quite strange to their parents and the two parties sometimes move apart. As generation $Z$ was born into the world of technology and they feel good in that world, thus it is primarily important for them to be surrounded by that environment. They are always online on any technical device virtually, with no stop. It can be seen through their actions, as well which are in connection with their technical environment and which can appear as a tool or as a milieu in their life. Other forms of socialization are very difficult for them. Compared with generation $\mathrm{Y}$, the generation $\mathrm{Z}$ is not aware of the concept of struggling. They are practical, rather intelligent than wise and they like to take the lead as they are brave. They are more impatient and more agile than their predecessors and they look for new challenges and impulses continuously. They are not afraid of continuous changes and due to the world of internet they possess much information, but just to a certain extent. To solve problems, they try to find the solutions on the internet (Tari, 2011).

The Forbes Magazine has made a survey about generation $Z$ in North and South America, in Africa, in Europe, in Asia and in the Middle East. 49 thousand youngsters were asked (Dill, 2015). On the basis of the results it can be said that $Z$ generation is the first real global generation. High-tech is in their blood, they have grown up in uncertain and complex environment which determines their viewpoint about work, studying and the world. Arising from their habit, they have different expectations in their workplaces. We can speak about a careerist, professionally ambitious generation, but their technical- and language knowledge are on a high level. Therefore, they are excellent workforces. Employers have to prepare to engage $Z$ generation with regard to speaking to them efficiently, to fit them into the community, the organizational culture and to make them effective employees in the digital age (Elmore, 2014). 
Employers have to face the fact that this generation will choose a career of their own interest, not because they want to meet demands of anybody. The result of this behaviour is an intrinsic motivation, they have a tough enterprising spirit and they want to influence the world. At the same time, their most important career goals are the work-life balance and a workplace stability. Z generation is not as optimistic as their predecessors were from the viewpoint of the workplace. A part of them worry about unemployment, or if their career can get stuck and they cannot evolve their talent. The members of $\mathrm{Y}$ generation are afraid of becoming an adult and of responsibility, and they think the world of work is cold and rejecting. These two generations handle the process of job-hunting negatively because they cannot receive feedback at all. The X generation had a bit easier situation in the labour market, they faced rejection as adults (Durbák, 2013). A virtual world is natural for $\mathrm{Y}$ and $\mathrm{Z}$, but a lot of them cannot fit their online life into their offline life. They feel some gap between reality and desires is irreconsiable, and they feel the uncertainty of existence. They are anxious, disappointed, they sit at home and they are waiting for somebody to pay attention to them and to give a feedback to them that was often told by their parents: they are fantastic (Tari, 2011).

Using smart applications is quite widespread among them, and these applications further make their everyday life easier, but faster. Generation $\mathrm{Z}$ is just partly present at the labour market, but they surprise their colleagues and the HR managers. The key to the classical market success and at the same time, the requirement of the corporate management is to have people who reach their aim by cooperating and by sharing their knowledge. In order to reach this aim, it is necessary for different generations to cooperate with each other (team work, knowledge sharing), they have common goals, they are devoted to do their job, they provide and ask for help and of course, they trust each other to share their knowledge (Elmore, 2010).

Table 1 below shows the two determining characteristics which play the most important role in both daily life and in the life of a successful company as well. These characteristics arise most frequently when attention is focused onto the kind of behaviour expected if the generational differences are to be addressed (Tóth-Bordásné \& Bencsik, 2011).

Tab. 1 - Different generational characteristics from a viewpoint of teamwork and knowledge sharing Source: Tóth-Bordásné \& Bencsik, 2011.

\begin{tabular}{|l|c|c|c|c|}
\hline & Baby - boom & X generation & Y generation & Z generation \\
\hline Teamwork & Unknown & $\begin{array}{c}\text { Natural environ- } \\
\text { ment (multina- } \\
\text { tional companies) }\end{array}$ & $\begin{array}{c}\text { Belief in the suc- } \\
\text { cess of common } \\
\text { effort }\end{array}$ & $\begin{array}{c}\text { On a virtual level } \\
\text { (only if forced) }\end{array}$ \\
\hline $\begin{array}{l}\text { Knowledge } \\
\text { sharing }\end{array}$ & $\begin{array}{c}\text { Willingly, vol- } \\
\text { untarily }\end{array}$ & $\begin{array}{c}\text { It is based on } \\
\text { mutuality and } \\
\text { cooperation }\end{array}$ & $\begin{array}{c}\text { Only in cases of } \\
\text { self interest or if } \\
\text { forced }\end{array}$ & $\begin{array}{c}\text { On virtual } \\
\text { level, easily and } \\
\text { rapidly, no stake, } \\
\text { publically }\end{array}$ \\
\hline
\end{tabular}

In Table 2 we can see the noted characteristics which represent a challenge from the respect of knowledge sharing and intergeneration management (Bencsik \& Machova, 2016). 
Tab. 2 - Generational behavioural characteristics of different age-groups Source: Bencsik \& Machova, 2016.

\begin{tabular}{|c|c|c|c|c|}
\hline & Baby - boom & $\mathrm{X}$ generation & Y generation & $\mathrm{Z}$ generation \\
\hline View & $\begin{array}{l}\text { Communal, } \\
\text { unified think- } \\
\text { ing }\end{array}$ & $\begin{array}{l}\text { Self-centred and } \\
\text { medium-term }\end{array}$ & $\begin{array}{l}\text { Egotistical, short- } \\
\text { term }\end{array}$ & $\begin{array}{c}\text { No sense of } \\
\text { commitment, be } \\
\text { happy with what } \\
\text { you have and live } \\
\text { for the present }\end{array}$ \\
\hline $\begin{array}{l}\text { Relation- } \\
\text { ship }\end{array}$ & $\begin{array}{l}\text { First and fore- } \\
\text { most personal }\end{array}$ & $\begin{array}{l}\text { Personal and vir- } \\
\text { tual networks }\end{array}$ & $\begin{array}{l}\text { Principally vir- } \\
\text { tual, network }\end{array}$ & $\begin{array}{l}\text { Virtual and su- } \\
\text { perficial }\end{array}$ \\
\hline Aim & Solid existence & $\begin{array}{l}\text { Multi-environ- } \\
\text { ment, secure } \\
\text { position }\end{array}$ & $\begin{array}{l}\text { Rivalry for leader } \\
\text { position }\end{array}$ & $\begin{array}{l}\text { Live for the } \\
\text { present }\end{array}$ \\
\hline $\begin{array}{l}\text { Self- } \\
\text { realization }\end{array}$ & $\begin{array}{l}\text { Conscious car- } \\
\text { rier building }\end{array}$ & Rapid promotion & Immediate & $\begin{array}{l}\text { Questions the } \\
\text { need for it at all }\end{array}$ \\
\hline IT & $\begin{array}{l}\text { It is based on } \\
\text { self-instruction } \\
\text { and incomplete }\end{array}$ & $\begin{array}{c}\text { Uses with confi- } \\
\text { dence }\end{array}$ & $\begin{array}{c}\text { Part of its every- } \\
\text { day life }\end{array}$ & Intuitive \\
\hline Values & $\begin{array}{l}\text { Patience, soft } \\
\text { skills, respect } \\
\text { for traditions, } \\
\text { EQ, hard work, }\end{array}$ & $\begin{array}{l}\text { Hard work, open- } \\
\text { ness, respect for } \\
\text { diversity, curios- } \\
\text { ity, practicality }\end{array}$ & $\begin{array}{l}\text { Flexibility, mobil- } \\
\text { ity, broad but } \\
\text { superficial knowl- } \\
\text { edge, success } \\
\text { orientation, crea- } \\
\text { tivity, freedom of } \\
\text { information takes } \\
\text { priority }\end{array}$ & $\begin{array}{l}\text { Live for the } \\
\text { present, rapid } \\
\text { reaction to eve- } \\
\text { rything, initiator, } \\
\text { brave, rapid infor- } \\
\text { mation access and } \\
\text { content search }\end{array}$ \\
\hline $\begin{array}{l}\text { Other possi- } \\
\text { ble charac- } \\
\text { teristics }\end{array}$ & $\begin{array}{l}\text { Respect for } \\
\text { hierarchy, exag- } \\
\text { gerated mod- } \\
\text { esty or arrogant } \\
\text { inflexibility, } \\
\text { passivity, cyni- } \\
\text { cism, disap- } \\
\text { pointment }\end{array}$ & $\begin{array}{l}\text { Rule abiding, } \\
\text { materialistic, fair } \\
\text { play, less respect } \\
\text { for hierarchy, has } \\
\text { a sense of relativ- } \\
\text { ity, need to prove } \\
\text { themselves }\end{array}$ & $\begin{array}{l}\text { Desire for } \\
\text { independence, } \\
\text { no respect for } \\
\text { tradition, quest } \\
\text { for new forms } \\
\text { of knowledge, } \\
\text { inverse socializa- } \\
\text { tion, arrogant, } \\
\text { home office and- } \\
\text { part-time work, } \\
\text { interim manage- } \\
\text { ment, undervalue } \\
\text { soft skills and EQ }\end{array}$ & $\begin{array}{l}\text { Differing view- } \\
\text { points, lack of } \\
\text { thinking, hap- } \\
\text { piness, pleasure, } \\
\text { divided attention, } \\
\text { lack of conse- } \\
\text { quential thinking, } \\
\text { no desire to make } \\
\text { sense of things, } \\
\text { the boundaries of } \\
\text { work and enter- } \\
\text { tainment overlap, } \\
\text { feel at home } \\
\text { anywhere }\end{array}$ \\
\hline
\end{tabular}


The table shows similarities, easily handled gaps and discrepancies. Management, however, has to deal with serious generational differences if the aim that knowledge sharing, as the result of the work of a collaborative organisational community, is to be realized.

\subsection{HR challenges}

Although the traditional HR activities have developed in methodology a lot recently, they remained at their original fields, such as recruitment, employing, performance evaluation, developing motivation and payment systems, career management, etc. The requirements of the youngest generations rewrite these activities radically. Not only the mentioned fields, but their tools mean challenges for the HR. New and previously not used solutions should be used such as developing satellite workplaces, hot desk, shared desk, open space, break out, mobile centre, green HR, activity based working, developing business partners, etc. All these activities strongly relate to the behaviour of the above mentioned new generations and to the changes in the requirements. Market competition, staying alive and the need to get and to share knowledge mean significant stress towards the direction of change, which will become the basic principle of the competitive operation in the future. The HR fields have to be prepared for these challenges. Table 3 represents an extract of the necessary changes depicting the features, which are important from the aspect of the present research. Of course the HR challenges will not stop at this level. Further theoretical and practical examinations are necessary in order to adapt the present changes to the corporate practice. The table summarizes the most important HR challenges, which have been in the focus since the new generations appeared at the workplaces.

It aims to show that the methodology which supports collaboration and knowledge sharing in these critical areas can be successfully realized if the characteristics of different generations are kept in focus.

Tab. 3 - Challenges of the HR in the light of different generational characteristics Source: Bencsik \& Machova, 2016.

\begin{tabular}{|c|c|c|c|c|}
\hline & Baby - boom & $\mathrm{X}$ generation & Y generation & $\mathrm{Z}$ generation \\
\hline $\begin{array}{l}\text { Incentive/ } \\
\text { motivation }\end{array}$ & $\begin{array}{l}\text { Promotion } \\
\text { opportunity, } \\
\text { new paths, } \\
\text { fixed work } \\
\text { place }\end{array}$ & $\begin{array}{c}\text { Status, } \\
\text { materialism }\end{array}$ & $\begin{array}{l}\text { Individual } \\
\text { freedom of } \\
\text { movement, } \\
\text { opportunity to } \\
\text { make decisions, } \\
\text { competition, self- } \\
\text { realization }\end{array}$ & $\begin{array}{l}\text { Immediate } \\
\text { remuneration, } \\
\text { freedom, non- } \\
\text { commitment }\end{array}$ \\
\hline $\begin{array}{l}\text { Performance } \\
\text { evaluation }\end{array}$ & $\begin{array}{l}\text { Fact based, } \\
\text { correct, based } \\
\text { on the past }\end{array}$ & $\begin{array}{l}\text { Future-oriented, } \\
\text { active participa- } \\
\text { tion, goal setting, } \\
\text { carreer planning }\end{array}$ & $\begin{array}{l}\text { Future-oriented, } \\
\text { direct feedback, } \\
\text { discussion, talent } \\
\text { management }\end{array}$ & $\begin{array}{l}\text { Own limits not } \\
\text { recognised, self- } \\
\text { confident, values } \\
\text { and self-image is } \\
\text { distorted }\end{array}$ \\
\hline
\end{tabular}




\begin{tabular}{|l|c|c|c|c|}
\hline $\begin{array}{l}\text { Training, } \\
\text { learning, } \\
\text { development }\end{array}$ & $\begin{array}{c}\text { Traditional } \\
\text { education sys- } \\
\text { tem, experi- } \\
\text { ence, holistic }\end{array}$ & $\begin{array}{c}\text { Flexible, shorter } \\
\text { learning time, } \\
\text { trainings, mim- } \\
\text { icry, interactive, } \\
\text { flexible, just in } \\
\text { case }\end{array}$ & $\begin{array}{c}\text { Rapid, individual, } \\
\text { based on IT, } \\
\text { alternative, just in } \\
\text { time }\end{array}$ & $\begin{array}{c}\text { Based on interest, } \\
\text { informal learning }\end{array}$ \\
\hline $\begin{array}{l}\text { Conflict } \\
\text { management }\end{array}$ & $\begin{array}{c}\text { Avoids or } \\
\text { deals with }\end{array}$ & $\begin{array}{c}\text { Willing to com- } \\
\text { promise }\end{array}$ & Opposes & $\begin{array}{c}\text { Provokes con- } \\
\text { flicts, but either } \\
\text { does not follow } \\
\text { through or reacts } \\
\text { aggressively }\end{array}$ \\
\hline
\end{tabular}

It goes without saying that success always depends on the level of preparation, on the leadership style and on other circumstances. This means that the challenges, as introduced in this chapter, faced by company HR departments should not be neglected and it can be of great help to know the family background of employees and the emotional baggage that they bring with them. If these factors are kept in mind, generational problems can be alleviated. If the trust is established, then cooperation and a more pliable form of knowledge sharing will follow and will contribute to the successful, competitive running of a company. It is worth taking a look into the family background of future colleagues, key personnel and managers whilst carrying out the more familiar HR processes such as training, the manager selection process, skills management and career planning (Bencsik 2010). Building and maintaining an atmosphere of trust where collaboration, knowledge sharing can thrive, considered as the key factor to company success and competitiveness, all depends on the behaviour of those who have either experienced, or indeed never felt, the power of trust.

Based on the above presented generation features and HR challenges the question that motivated the research of the authors was asking how to reveal, motivate or perhaps influence the two youngest age groups' workplace attitudes, and their willingness to help and to cooperate by the tools of HR. The test of practical life gives the following results.

\section{DETAILS OF THE RESEARCH}

\subsection{Materials and Procedures}

The research was carried out last year (2015). The aim of the authors was to get to know as many age groups' opinion as they could about the generation $\mathrm{Y}$ and $\mathrm{Z}$ and about the ways how these two generations can fit into their workplaces and what challenges their appearance mean for the HR managers and for the management. The research on one hand consisted of secunder research, that it focused on studying the previous literature in that topic, while on the other hand the research contained quantitative (questionnaires) and qualitative (in-depth interviews and focus group) studies. The results of the questionnaire-based research will be shown in the followings; and their verification was implemented by the qualitative methods.

The respondents had to fill in a questionnaire on the internet, which mainly consisted of closed 
questions, and there were only three open questions to answer. The closed questions were built on nominal and metric scales, and within this the authors used the 5-points Likert scale. The questions were divided into three groups. The first group of questions discussed the conflicts between the different generations, also it discussed their form of appearance in work and in human relations at workplaces; furthermore it examined the opportunities how to solve these conflicts. The second group of questions was about age-groups, while the last group of questions was about the specification of the sample.

Filling the questionnaire was anonymous, the method for collecting samples was the snowball method, and therefore the sample cannot be considered representative.

The evaluation was carried out with the help of SPSS program by using one-or more variablestatistical methods such as frequency, average, deviation, crossboard-analysis, and Khi-square test and ANOVA method.

The specification of the sample is the following:

A sample of 410 pieces was collected in the research and all the questionnaires could be used in the evaluation process.

The youngest respondent was 18 years old, while the oldest was 64 . The authors divided the sample into 5 age-groups, according to which the classification of the respondents is the following: $3.2 \%$ of the respondents were under $20,48.1 \%$ of them were between 20 and 30, $22.9 \%$ were between 30 and 40, 18.1\% were between 40 and 50; while $7.7 \%$ of the respondents were over 50 years old. The authors considered it useful to divide the sample by ages, because the answers of the respondents could be analysed in more details, rather than dividing the respondents 'just' by generations. The other reason justifying this classification is that the research did not especially focus on generation $\mathrm{X}$.

According to the highest qualification of the respondents, $1.3 \%$ of them finished only primary school, $56.5 \%$-had high school degree, while $42.3 \%$ had university degree. The results of the crossboard based on the qualification and age-groups revealed that the age-group between 20 and 30 had secondary school education in the biggest proportion (57.8\%); more than $50 \%$ of the respondents between 30 and 50 also had secondary school education, while almost half of the respondents over 50 had higher education degree as well.

As far as the company, where the respondents were working is concerned, $26.7 \%$ of them were micro company with less than 10 employees, $41 \%$ were small enterprise with $11-49$ employees, $15.6 \%$ were middle-sized enterprise with $50-249$ employees, while $16.6 \%$ of them were big company employing at least 250 people.

Analysing the crossboard made from the age and size of the company, it could be seen that almost every seventh respondent between 20 and 40 in the sample was working for a big company, while in case of the employees over 50 this index increased to 12 . In the sample those with higher education qualification were mainly employed at middle-sized companies (53.8\%), while in cases of the employees with secondary qualification this ratio was divided between small enterprises and middle-sized companies (31.8\%-31.8\%). 


\section{RESULTS AND DISCUSSION}

In the research, the authors performed -among others- the justification of the validation of the following hypothesis.

\section{Hypothesis}

According to the respondents participating in the sample, certain changes should be implemented in the activities of HR due to the appearance of generation $\mathrm{Z}$ and generation $\mathrm{Y}$.

In the first part of the research, the authors analysed the opinions of the respondents about the employees under 30. Numerous features were enumerated and the respondents had to value on a 5-point Likert-scale how that given characteristic feature was typical of that age-group (table 4).

Tab. 4 - Judgement of the age-group who is under 30 (average and deviation) Source: authors' construction

\begin{tabular}{|c|c|c|c|c|}
\hline \multirow{3}{*}{ Variables } & \multicolumn{4}{|c|}{ Statistics } \\
\hline & \multicolumn{2}{|c|}{$\mathbf{N}$} & \multirow{2}{*}{ Mean } & \multirow{2}{*}{$\begin{array}{c}\text { Std. } \\
\text { Deviation }\end{array}$} \\
\hline & Valid & Missing & & \\
\hline Moderate & 308 & 102 & 2.31 & 0.894 \\
\hline Committed & 308 & 102 & 2.80 & 0.979 \\
\hline Disrespectful & 312 & 98 & 2.82 & 1.014 \\
\hline Working hard & 306 & 104 & 2.82 & 1.003 \\
\hline Having no values & 307 & 103 & 2.83 & 0.998 \\
\hline Well-mannered & 313 & 97 & 2.90 & 0.925 \\
\hline $\begin{array}{l}\text { Warmly welcome by the } \\
\text { others }\end{array}$ & 315 & 95 & 2.91 & 1,06 \\
\hline Work hard & 308 & 102 & 2.93 & 1.023 \\
\hline Share their knowledge & 314 & 96 & 2.96 & 0.918 \\
\hline Persistent & 311 & 99 & 2.98 & 0.975 \\
\hline Help others with pleasure & 312 & 98 & 2.99 & 0.945 \\
\hline $\mathrm{Bad}$ & 312 & 98 & 3.01 & 1.07 \\
\hline Selfish & 311 & 99 & 3.02 & 1.062 \\
\hline $\begin{array}{l}\text { Having good problem- } \\
\text { solving skills }\end{array}$ & 312 & 98 & 3.08 & 0.849 \\
\hline Work independently & 313 & 97 & 3.11 & 0.908 \\
\hline Cooperative & 311 & 99 & 3.13 & 0.885 \\
\hline Motivated & 310 & 100 & 3.26 & 0.986 \\
\hline Smart & 312 & 98 & 3.29 & 0.781 \\
\hline Expect help & 312 & 98 & 3,31 & 0.986 \\
\hline Purposive & 309 & 101 & 3.33 & 1 \\
\hline
\end{tabular}




\begin{tabular}{|l|c|c|c|c|}
\hline Like teamwork & 306 & 104 & 3.38 & 0.962 \\
\hline Full of ideas & 312 & 98 & 3,45 & 0.961 \\
\hline Can communicate well & 310 & 100 & 3,50 & 0.88 \\
\hline Having strong career desire & 311 & 99 & 3.60 & 0.988 \\
\hline Creative & 313 & 97 & 3.68 & 0.776 \\
\hline $\begin{array}{l}\text { Having too much self- } \\
\text { confidence }\end{array}$ & 308 & 102 & 3.84 & 1.055 \\
\hline
\end{tabular}

From the table it can clearly be seen that according to the respondents, most typical characteristic features of the youngest age-groups were the following: they have too much self-confidence, they are creative, they have strong career desires and their communication is perfect while they are not at all moderate, committed or work hard.

The authors examined whether there was difference between the judgements of each feature based on the age-groups. Therefore, the ANOVA test found significant differences based on the following features at the level of 0.05 significance: smart (F: 2.522 sign. .041), motivated (F: 3.071 sign. .017), selfish (F: 4.182 sign. .003), work hard (F: 3.045 sign. .018), expect help (F: 3.295 sign. .012), persistent (F: 3.052 sign...017). Based on the average values, the authors concluded that it was the generation $\mathrm{Z}$ and $\mathrm{Y}$, who typically judged themselves more positive than the older age-groups judged them.

The authors asked the respondents about the activities, where the generation $\mathrm{Z}$ and generation Y performed better than the older generations. According to the respondents, the employees under 30 perform better mainly in the field of IT and in activities which require creativity or innovation. At the same time the respondents valued that the above mentioned generations did not like monotony, individual activities, marketing and they also performed poorer than their older colleagues in the field of administration.

It is natural to ask the question whether the age-consistency caused any problems at work within an organization. $34.4 \%$ of the respondents answered yes, $14.8 \%$ could not answer. However, almost half of the sample answered that it did not cause any conflicts. Based on the Khi-square test, it was examined whether there was significant correspondence in the answers based on the ages. The results of the test did not show such correspondence (Pearson's Khi-square: $6.494 \mathrm{df}$ : 8 sign. $.592 \mathrm{p}>.05$ ). The results of the crossboards showed that among the people between 30 and 50, every second respondent did not feel any problems; less than half of the people between 20 and 30 shared the same opinion; and people over 50 had the same opinion as well.

The respondents who answered that this cooperation was problematic had to answer another question answering where these conflicts appear during common work. The respondents had to choose among problems given by the authors and they had to tell whether that given question emerged or not. The respondents could mark more options in the research. The frequency of the answers can be seen in table 5 . 
Tab.5 - Sources of conflict (N, \%) Source: authors' construction

\begin{tabular}{|l|c|c|}
\hline Features & N & \% \\
\hline Usage of tools & 10 & $3 \%$ \\
\hline Incompatibility & 14 & $4 \%$ \\
\hline Problem concerning method of work & 21 & $7 \%$ \\
\hline Problem caused by the working style & 26 & $8 \%$ \\
\hline Disrespect & 42 & $13 \%$ \\
\hline Problem caused by work-speed & 46 & $15 \%$ \\
\hline Problems concerning sharing work & 47 & $15 \%$ \\
\hline Problem in their way of thinking & 52 & $17 \%$ \\
\hline Communication problem & 55 & $18 \%$ \\
\hline & 313 & 100 \\
\hline
\end{tabular}

Based on the data, it is mainly the communication and the difference in the way of thinking that can cause difficulties in the process of working together. Of course, this tense situation has to be solved. According to the participants, the best way to solve the difficulties is discussion and managerial intervention. It was interesting to see that 24 respondents answered that the best solution is shouting, while 16 of them said that this question was not worth dealing with.

The question is whether it is the labour market-presentation of the generation under 30 who induces the change in the managing of the staff within an organization or in the activities connected to them. $44.5 \%$ of the participants in the research answered yes, $33.2 \%$ said no, while $22.3 \%$ could not answer the question. There was no significant correlation between the answer and the age-groups: Khi- square test: Khi-square: $14.122 \mathrm{df:} 8$ sign. $.079 \mathrm{p}>.05$. Half of the respondents over 30 answered that it was necessary to change in the management. The authors enumerated different changes for the respondents and they could choose more than one from the list. The frequency of the answers is summarized in table 6.

Tab. 6 - Solution possibilities (N. \%) Source: authors' construction

\begin{tabular}{|l|c|c|}
\hline Alteration possibilities & $\mathbf{N}$ & $\mathbf{0}$ \\
\hline Corporate culture & 21 & $5 \%$ \\
\hline Expected competencies & 37 & $9 \%$ \\
\hline Team work & 42 & $10 \%$ \\
\hline Selection process & 45 & $11 \%$ \\
\hline Working method & 45 & $11 \%$ \\
\hline Qualitative level & 50 & $12 \%$ \\
\hline Work-speed & 55 & $13 \%$ \\
\hline Communication & 61 & $14 \%$ \\
\hline Performance expectation & 70 & $16 \%$ \\
\hline Total & 426 & $100 \%$ \\
\hline
\end{tabular}


The respondents mostly believed that expecting competencies and changing communication could lead to change in the handling of generation $\mathrm{Z}$ and generation $\mathrm{Y}$.

Phrasing the question further, the dilemma is conceived by the management and the HR colleagues regarding the tools and possibilities, which could help to keep these young adults at the given workplaces. Are new tools necessary or are the traditional ones appropriate enough? If they are, then what are the suggested solutions? The respondents had to value the enumerated possibilities on a 5 -point Likert scale to what extent they thought that solution was typical or not.

Tab.7 - Incentives for the young adults (N. \%) Source: authors' construction

\begin{tabular}{|c|c|c|c|c|}
\hline \multirow{2}{*}{ Variables } & \multicolumn{2}{|c|}{$\mathbf{N}$} & \multirow{2}{*}{ Mean } & \multirow{2}{*}{$\begin{array}{c}\text { Std. } \\
\text { Deviation }\end{array}$} \\
\hline & Valid & Missing & & \\
\hline with money & 316 & 94 & 4.53 & .741 \\
\hline with career opportunity & 308 & 102 & 4.19 & .820 \\
\hline with position & 308 & 102 & 3.85 & .860 \\
\hline with good workplace atmosphere & 312 & 98 & 3.71 & .869 \\
\hline with challenging work & 310 & 100 & 3.06 & .992 \\
\hline with extra cafeteria elements & 302 & 108 & 2.98 & .938 \\
\hline with high salary & 302 & 108 & 2.80 & 1.003 \\
\hline with non-material incentives & 299 & 111 & 2.25 & 1.006 \\
\hline with nothing & 298 & 112 & 1.70 & 1.006 \\
\hline
\end{tabular}

Based on the answers, it is mainly money and career opportunities which can motivate the young adults to stay at a company: it means that the traditional tools are more motivating than the non-material incentives. This research results are somehow similar to the research carried out by Czeglédi-Juhász in 2013, where the authors examined what opportunities were ensured for entrants by the employers. From the results, it could be seen that the employers mainly offer opportunities in career development for the entrants and furthermore, they can provide good workplace atmosphere and training opportunities. At the same time it is important to note that the entrants knew that their salary requirement could not be high $(35.8 \%$ of the respondents answered that out of 157 entrants).

In the research the authors examined whether the different age-groups had different opinions regarding each aspect. Significant difference can only be observed in case of position, where the highest average was judged by the age-group 20-30, thus they considered position important. At the same time the people over 51 and under 20 did not consider it that important in the dimension of generation $\mathrm{Y}$ and $\mathrm{Z}$.

Finally it was discussed in the questionnaire which age-groups they could work together with. Almost $44.4 \%$ of the respondents could establish good working relationship with the young adults in their 20 's; $37.6 \%$ answered that that they would rather work with the young adults over 30 ; while $15.6 \%$ of the respondents would have that relationship with people over 40 and only $2.4 \%$ could work together with the youngest age-groups, with youngsters under 20 . The cross- 
boards showed that in case of each generation, it is their own age-group they can work together with the most. Of course, the cooperation of different generations can have more positive benefits for the companies. According to the respondents the advantages are among others: mutual help, respect, better ideas and motivating atmosphere, which by all means can motivate the work of the individuals and the company.

\section{DISCUSSION}

The aim of the research was to examine the characteristic features, which emerge in case of the youngest generations in the labour-market and what challenges their different behaviour mean in the workplace environment during the cooperation of more generations. The research was based on questionnaires, and in the evaluation process we could justify our hypothesis, namely that the HR managers have to cope with new tasks if they want to capture and keep the young employees and to ensure knowledge-sharing, which is the key to competitiveness. Because this topic is relatively new, the results can be compared only with some earlier results. Some studies deal with the possible workplace problems in theory, which mean challenges for the management. Table 8 shows the difficulties Smith observes. (The newest generation, generation $Z$ is not mentioned in his work). Although the features summarized in the table are slightly different from what we examined, the majority of the features justify our hypothesis and are in correlation with our results. Terepocki (2013) also summarizes in theory the eight most important fields, where the management have to cope with serious challenges and he draws the attention to the necessary tasks. These fields are the following: The fields mentioned by the author correspond with our research results totally. The study of Chen (2015) specifically deals with HR-activities, where he offers theoretical solutions focusing on the main activities. He believes that the majority of problems come from getting the employees, cultural background, managing the communication problems between generations, the opportunities for career-building and replacing lost knowledge due to retirement. The thoughts of Chen also comply with our own results. As it was previously mentioned above, the researches primarily deal with the challenges theoretically and it is not yet possible to compare our results with results of practical researches. Results of practical researches can rather be seen in situations outside workplaces. Previous articles examined the behaviour of new generations and their willingness to share their knowledge (Bencsik, 2015; Gutierrez, 2016), but not the work environment first of all. (The results of these papers are in harmony with the results of ours.) As the $\mathrm{Z}$ generation is on the labour market and in the workplaces only in a fewer number that is why, their problems do not appear too sharply and in a bigger measure. The leaders, managers and HR experts have to prepare for these challenges and the researches have started in this area (Olšovská et al, 2016). Intergeneration communication and information sharing, their technics are very different from the previous generations which will lead to a lot of conflicts and give rise to a misunderstanding (Dill, 2015). The members of $Y$ generation achieve antipathy of their surroundings and cause conflict situations by their self-assurance, by their persuasions which do not tolerate criticism or contradiction, by their overconfidence and career desire. According to our results, these young people do not tolerate monotony, individualistic actions or tasks which require thinking (Olšovská et al., 2015). Their behaviour is determined by the culture and value system which are brought from home. The effects of these 
features require additional researches. $\mathrm{Y}$ and $\mathrm{Z}$ generations are distrustful, they do not help each other, they build connections only superficially (Elmore, 2014). An interesting result that these two generations which are closest to each other can least work together. Y generation can work together with $\mathrm{X}$ generation for common goals, but $\mathrm{Z}$ generation wants to achieve success alone (The Forum, 2016). Previous researches confirm that these young people are clever, they have such abilities which are necessary in the labour market. But to adapt them and to keep them in the companies, to find the best motivational tools are really serious tasks for companies (Cook, 2016). Although the previous researches of Czeglédi-Juhász (2013, 2015) also justified the fact that the needs of the employers and employees with the age-group under 30 and the workplace requiremenst are not always in balance claim a new way of thinking from the HR, which was justified by the present research.

The difficulty of financing is one obstacle of the research, which was rather problematic in case of collecting samples and in case of the method of sampling. In case of getting financial support, we would expand the samples and we would prepare international comparison in the future.

\section{CONCLUSIONS}

The present paper illustrates some results of last year's research, which examined the organizational effects and $\mathrm{HR}$ activities connected to appearance of generation $\mathrm{Z}$ and $\mathrm{Y}$ in labour market. In the light of the research results, the hypothesis conceived by the authors can be accepted. Although it has to mentioned that the validity of the given hypothesis is justified only within the frame of the given research, which cannot be considered representative. Nevertheless the study draws the attention to several thought-provoking issues. The research justified that the cooperation of different age-groups could provide not only conflicts, but positive results as well for the organisation, of which additive implementation the HR has important roles. Changing present HR activities is by all means necessary in order to have the new generation with their new requirements and new features as active and productive members of the organisation. These changes primarily affect communication, motivation and development of corporate culture. Authors' results correspond with the results of the previous years (Krishnan et al, 2012; Singh, 2014; Schaffer, 2015; Tari, 2011) they see these generations as open and purposeful, but researchers have identified a lot of features which mean challenges for HR experts. Establishing patience, understanding, empathy and re-arranging organisations, establishing the technical background all mean managerial challenges and all the organisations have to start preparing for these changes in time.

\section{References}

1. Bencsik, A. (2015). A tudásmenedžsment elmélete és g yakorlata. Budapest: Akadémiai Kiadó.

2. Bencsik, A., \& Machova, R. (2016, April). Knowledge Sharing Problems from the Viewpoint of Intergeneration Management. In ICMLG2016 - 4th International Conference on Management, Leadership and Governance: ICMLG2016 (p. 42). Academic Conferences and publishing limited. 
3. Bittner, Z., Kehl, D., \& Szűcs, K. (2013). Tudománykommunikáció a Z generációnak, Pécsi Tudományegyetem, Pécs, Készült a TÁMOP-4.2.3-12/1/KONV-2012-0016 Tudománykommunikáció a Z generációnak projekt keretében. Retrieved May 16, 2016, from http://www.zgeneracio.hu/tanulmanyok.

4. Chan, A. (2015). Cross-Generation Communication, Collaboration and Creativity Retrieved February 08, 2016, from http://www.hrvoice.org/cross-generation-communicationcollaboration-and-creativity/

5. Cook, V. S. (2016). Engaging Generation Z Students. Retrieved May 07, 2016 from https://sites. google.com/a/uis.edu/colrs_cook/home/engaging-generation-z-students.

6. Czeglédi, Cs. \& Juhász, T. (2013). A pályakezdők munkaerő-piaci megfelelése a pályakezdők szemszögéből Kaposvári konferencia 2013.10. 13. Taylor. 3-4 (16-17), 91-97.

7. Czeglédi, Cs., \& Juhász, T. (2015). Mit várunk el a pályakezdőktől? Vélemények és szempontok a cégek oldaláról Gödöllői konferencia (2015.05.09.) Studia Mundi. 2(3), 55-63.

8. Davenport, H. T., \& Prusak, L. (2001). Tudásmenedæsment, Budapest: Kossuth Kiadó, 195.

9. Dill, K. (2015). 7 Things Employers Should Know About The Gen Z Workforce, Forbes Magazin, 11.6. Retrieved March 16, 2016, from http://www.forbes.com/sites/ kathryndill/2015/11/06/7-things-employers-should-know-about-the-gen-z-workforce/ print/.

10. Durbák, I. (2013). Miért nem érti eg ymást aq X, Y és a $Z$ generáció? (Vajon mek.kora az X, Y és Z generációk közötti sz̧akadék a munkaeröpiacon? Retrieved November 12, 2014, from https://www.profession.hu/cikk/20131018/miert_nem_erti_egymast_az_x_y_es_a_z_ generacio/3530.

11. Elmore, T. (2014). How Generation Z Differs from Generation Y. Retrieved July 01, 2015, from http://growingleaders.com/blog/generation-z-differs-generation-y/.

12. Guttierrez, K. (2016). Be Ready! Millennials Are Calling the Shots in the eLearning Industry. Retrieved June 26, 2016, from http://info.shiftelearning.com/blog/millennials-elearningindustry?utm_source=hs_email\&utm_medium $=$ email\&utm_content $=21296196 \&$ _ hsenc=p2ANqtz-81MNpgmqrNECiOsGR3mQn9oUuGdqeKsIYEB5Zc4UnHKL8L_GIa ho8vtrDtvxXcEMRW9vXMMcMfWVvAF6fsApD1zI9vmA\&_hsmi=21296196

13. Howe, N., \& Strauss, W. (2009). Millennials Rising: The Next Great Generation, Knopf Doubleday Publishing Group

14. Krishnan, S. K., Bopaiah, S., Bajaj, D., \& Prasad R. (2013). Organization, Generation, and Communication - Infosys Experience. NHRD Journal. 10, 85-93.

15. Olšovská, A., Mura, L., \& Švec, M. (2015). The most recent legislative changes and their impact on interest by enterprises in agency employment: what is next in human resource management? Problems and Perspectives in Management. 13 (3). 47-54

16. Olšovská, A., Mura, L., \& Švec, M. (2016). Personnel Management in Slovakia: Current Latent Issues. Mediterranean Journal of Social Sciences, 7 (2). 12-19.

17. Pais, E. (2015). Y és $Z$ generáció, mint a jövő munkavállalói, Retrieved December 16, 2015, from http://www.kormanyhivatal.hu/download/2/18/60000/Y\%20\%C3\%A9s\%20Z\%20gener \%C3\%A1ci $\%$ C3\%B3\%20mint $\% 20 a \% 20 j \% C 3 \% B 6 v \% C 5 \% 91 \% 20$ munkav $\%$ C3 $\%$ A 11 llal $\%$ C $3 \%$ B3i.pdf. 
18. Singh, A. (2014). Challenges and Issues of Generation Z, IOSR Journal of Business and Management (IOSR-JBM), 16 (7). 59-63.

19. Schäffer, B. (2015). A legifjabb titánok. Hungary: Book Kiadó.

20. Schäffer, B. (2012). Ifjú titánok. Budapest: Könyvműhely Kiadó.

21. Smith, G. (2013). Managing Generations in the Workplace. Retrieved February 08, 2016, form http://www.hrvoice.org/managing-generations-in-the-workplace/

22. Tari, A. (2010). Y generáció. Budapest: Jaffa Kiadó.

23. Tari, A. (2011). Z generáció. Budapest: Tericum Kiadó Kft.

24. Terepocki, J. (2013). XYBOOM: 8 Key Generational Issues (\& Opportunities) Retrieved March 08, 2016, from http://www.hrvoice.org/xyboom-8-key-generational-issues-opportunities/.

25. The Forum Generation Z report - A study into the next generation of workers (2016). Retrieved May 16, 2016, from www.forum.com.

26. Zemke, R., Raines, C., \& Filipczak, B. (2000). Generations at Work: Managing the Clash of Veterans, Boomers, Xers, and Nexters in Your Workplace. New York: American Management Association

\section{Contact information}

Prof. Dr. habil Andrea Bencsik.

Széchenyi István University in Györ

Faculty of Economics

Egyetem tér 1, 9026. Györ,

Hungary

E-mail:bencsik.andrea@yahoo.com

Dr.Timea Juhász

freelancer

E-mail:juhasæ.timi@hotmail.com

Gabriella Horváth-Csikés

Szent István University in Gödöllo"

Office of Rector

Páter K. u.1., 2100. Gödölló

Hungary

E-mail: horvathcsikosgabi@gmail.com 